SEA Volume 8, No. 2 (2019)

\title{
PROMOSI APLIKASI "SAYURBABA" TERHADAP KEPUTUSAN PEMBELIAN MELALUI MEDIA DIGITAL DI PONTIANAK
}

\author{
Putri Maylita Wiani ${ }^{* 1}$, Eva Dolorosa ${ }^{2)}$, Dewi Kurniati ${ }^{2)}$ \\ 1) Mahasiswa Program Studi Agribisnis Fakultas Pertanian Universitas Tanjungpura \\ ${ }^{2)}$ Dosen Program Studi Agribisnis Fakultas Pertanian Universitas Tanjungpura
}

Email: putrimaylita@gmail.com

\begin{abstract}
Nowadays many emerging businesses use digital media accounts to advertise their products, therefore the competition in business becomes tougher. Businessman should pay attention to promotional components through digital media in accordance with their target market to make the message provided effective, efficient and meet the intended use.The purposes is to structure the promotion of application sayurbaba on purchasing decisions trough digital media in Pontianak city. Survey method with 100 respondents by purposive sampling. Data collected through online questionnaires via google form. The analysis using Structural Equation Modeling through LISREL 8.80 software. The results proved that promotion of application Sayurbaba on purchasing decisions trough digital media in Pontianak city was composed of collaboration and connection components which were measured by sharing posts, customer testimonials, useful content and promotions.
\end{abstract}

Keywords: Context,Communication, Collaboration, Connection, SEM

\section{PENDAHULUAN}

Perkembangan teknologi yang canggih dengan jaringan internet dapat memudahkan interaksi secara langsung antara konsumen dan produsen. Para pelaku bisnis dapat melakukan apapun baik sekedar mencari informasi atau menjalankan bisnis. Konsumen juga semakin pintar dalam memilih dan membandingkan barang yang akan dibeli. Keadaan tersebut menuntut produsen untuk lebih jeli melihat peluang pasar yang ada (Kotler \& Keller, 2014).

CV. Sayurbaba Online Borneo merupakan salah satu perusahaan yang memanfaatkan era digital dalam menjalankan usahanya. CV. Sayurbaba Online Borneo startup berbasis digital pertama di Pontianak dalam bidang pelayanan jasa mengantar bahan makanan mentah, seperti sayuran, daging, ikan, dan bumbu masak. . Konsumen hanya perlu mengunduh aplikasi "Sayurbaba" pada Appstrore untuk gadget berbasis IOS maupun Playstore untuk gadget berbasis Android dan memesan kebutuhan dapur yang diperlukan atau dapat melalui website www.sayurbaba.com.

Era digital bukan hanya merubah cara mengakses informasi dengan lebih cepat, namun merubah cara melakukan bisnis dan promosi. Segala kemudahan dan manfaat media digital tidak serta merta dapat langsung meningkatkan keberhasilan dalam melakukan promosi. Terdapat hal-hal yang perlu diperhatikan perusahaan dalam memaksimalkan promosi melalui media digital. Beberapa penelitian terdahulu telah melakukan penelitian mengenai pentingnya mengetahui dampak konten post. Ditemukan bahwa konten post bisa memberi dampak pada metriks media digital Facebook dan Instagram: like dan komentar (Coelho, Oliveira, \& Almeida, 2016). Konten post bisa berdampak pada online engagement yang diwakili oleh like dan komentar (Lin \& Chiu, 2015). Tipe post dan waktu posting memiliki pengaruh signifikan terhadap online engagement (Santoso, Baihaqi, \& Persada, 
2017).Terdapat penelitian yang juga membahas mengenai dampak konten post terhadap popularitas brand-post (Vries, Gensler, \& Leeflang, 2012). Dalam hal ini faktor yang memengaruhi kepopuleran suatu post bisa diketahui dari jumlah like dan komentar (Ryan \& Zabin, 2010). Dampak dari suatu post dapat dilihat dari respon konsumen yang diwakili oleh like dan komentar tersebut. Semakin banyak jumlah like dan komentar maka semakin besar respon yang muncul dari konsumen. Dengan adanya respon yang banyak, hal ini menunjukkan bahwa suatu merek bisa menjalin hubungan dengan konsumen secara intens dan baik. Selain itu, jumlah like dan komentar yang banyak juga akan membuka peluang untuk sebuah merek agar lebih popular dan dikenal.

Promosi dikatakan efektif jika pesan yang disampaikan dapat sampai dan dimengerti oleh penerima pesan. Perusahaan dituntut lebih kreatif mempromosikan produk mereka di media digital untuk menarik para konsumen. Efektivitas promosi melalui media digital dapat dilihat dari perubahan sikap yang terjadi pada konsumen dan diukur dengan tahapan attention atau perhatian, interest atau ketertarikan, desire atau keinginan dan action atau tindakan keputusan pembelian. Adapun tujuan dari penelitian ini untuk menyusun promosi aplikasi "Sayurbaba" terhadap keputusan pembelian melalui media digital di kota Pontianak.

\section{METODE PENELITIAN}

Metode penelitian yang digunakan adalah metode kuantitatif dengan pendekatan penelitian deskriptif. Sampel dalam penelitian ini berjumlah 100 responden dengan teknik pengambilan sampel secara purposive sampling dengan kriteria responden berdomisili di Kota Pontianak, berusia 17 tahun ke atas dan memiliki setidaknya satu akun media digital instagram, facebook atau twitter dengan akun yang tidak dalam mode private. Teknik pengumpulan data dilakukan dengan wawancara dan penyebaran e-questionnaire google form melalui pesan langsung di media digital. Variabel laten endogen terdiri dari Context, Communication, Collaboration, Connection dan variabel laten eksogen diukur melalui AIDA yaitu Attention atau perhatian, Interest atau ketertarikkan, Desire atau keinginan, dan Actions atau tindakan.. Alat analisis pada penelitian ini menggunakan analisis Stuctural Equation Modelling (SEM) dengan software LISREL 8.80.

\section{HASIL DAN PEMBAHASAN}

Responden yang paling dominan berada di kategori 17-26 tahun. Media digital merupakan media yang aktif digunakan kalangan muda yang berusia 17-26 tahun di mana individu tersebut masih duduk di bangku perguruan tinggi. Hal tersebut juga dikemukakan oleh (Helianthusonfri, 2014) yang menyatakan bahwa kebanyakan pengguna media digital adalah kalangan muda.

Media digital yang mendominasi adalah instagram. Hal ini disebabkan CV. Sayurbaba Online Borneo lebih aktif menggunakan media digital instagram dibandingkan media digital lainnya. Responden dari media digital twitter selanjutnya tidak diikutkan dalam pengolahan data dikarenakan Sayurbaba di media digital twitter hanya memiliki 4 postingan dan 2 pengikut sehingga dianggap tidak dapat mewakilkan kegiatan promosi Sayurbaba di media digital. 
SEA Volume 8, No. 2 (2019)

Wilayah tempat tinggal didominasi oleh responden yang berada di wilayah kecamatan Pontianak Tenggara. Hal ini dikarenakan usia responden mayoritas berada pada usia 17-26 tahun di mana responden tersebut masih berstatus mahasiswa dan di wilayah kecamatan Pontianak Tenggara terdapat beberapa kampus yang tentunya banyak mahasiswa bertempat tinggal di sekitar kampus tersebut.

Jenis kelamin responden mayoritas adalah perempuan. Hal ini dikarenakan perempuan lebih ekspresif dibandingkan laki-laki sehingga jumlah pengguna media digital lebih didominasi oleh perempuan. Selain itu, menurut (Sumarwan, 2011) perempuan Indonesia pada masa kini memiliki kualitas sumberdaya manusia yang lebih baik dari generasi sebelumnya. Kualitas yang lebih baik inilah yang membuat perempuan sebagai konsumen memiliki daya beli yang baik juga. Terlebih didukung dengan adanya era digital yang mempermudah terlaksanakanya proses jual beli secara digital.

Status pernikahan didominasi oleh responden yang belum menikah. Hal ini disebabkan karena mayoritas pengguna media digital masih tergolong kalangan muda dimana individu tersebut masih duduk di bangku perguruan tinggi sehingga jumlah responden belum menikah lebih banyak dibandingkan responden yang sudah menikah.

Tabel 1. Karakteristik Responden

\begin{tabular}{|c|c|c|c|}
\hline Karakteristik & Keterangan & $\begin{array}{l}\text { Jumlah } \\
\text { (Orang) }\end{array}$ & Persentase $(\%)$ \\
\hline \multirow[t]{3}{*}{ Usia } & 17-26 Tahun & 77 & 70 \\
\hline & 27-36 Tahun & 26 & 23,6 \\
\hline & $>36$ Tahun & 7 & 6,4 \\
\hline \multirow[t]{3}{*}{ Media Digital } & Instagram & 70 & 63,6 \\
\hline & Facebook & 30 & 27,3 \\
\hline & Twitter & 10 & 9,1 \\
\hline \multirow[t]{6}{*}{ Wilayah } & Pontianak Tenggara & 38 & $\mathbf{3 4 , 5}$ \\
\hline & Pontianak Kota & 23 & 20,9 \\
\hline & Pontianak Selatan & 21 & 19,1 \\
\hline & Pontianak Barat & 12 & 10,9 \\
\hline & Pontianak Timur & 8 & 7,3 \\
\hline & Pontianak Utara & 8 & 7,3 \\
\hline \multirow[t]{2}{*}{ Jenis Kelamin } & Perempuan & 74 & 67,3 \\
\hline & Laki-Laki & 36 & 32,7 \\
\hline \multirow[t]{2}{*}{ Status } & Belum Menikah & 65 & 59,1 \\
\hline & Menikah & 45 & 40,9 \\
\hline \multirow[t]{5}{*}{ Pekerjaan } & Mahasiswa & 57 & 51,8 \\
\hline & Swasta & 30 & 27,3 \\
\hline & PNS & 12 & 10,9 \\
\hline & Wirausaha & 7 & 6,4 \\
\hline & IRT & 4 & 3,6 \\
\hline \multirow[t]{5}{*}{ Pengeluaran/bulan } & $>$ Rp.1.500.000 & $\mathbf{5 0}$ & 45,5 \\
\hline & Rp.1.500.000 - Rp.3.499.000 & 15 & 13,6 \\
\hline & Rp. 3.500.000 - Rp.5.499.000 & 25 & 22,7 \\
\hline & Rp. 5.500.000 - Rp.7.499.000 & 13 & 11,8 \\
\hline & > Rp. 7.499 .000 & 7 & 6,4 \\
\hline Frekuensi & Tidak Pernah & 5 & 4,5 \\
\hline \multirow{4}{*}{ Sayur/ Minggu } & 1-2 Kali & 22 & 20,0 \\
\hline & 3-4 Kali & 24 & 21,8 \\
\hline & 5-6 Kali & 17 & 15,5 \\
\hline & Setiap hari & 42 & 38,2 \\
\hline
\end{tabular}




\begin{tabular}{|c|c|c|c|}
\hline \multirow{5}{*}{$\begin{array}{l}\text { Frekuensi Transaksi } \\
\text { Online/ Bulan }\end{array}$} & Tidak pernah & 8 & 7,3 \\
\hline & 1-2 Kali & 57 & 51,8 \\
\hline & 3-4 Kali & 6 & 5,5 \\
\hline & 5-6 Kali & 10 & 9,1 \\
\hline & $>6$ Kali & 9 & 8,2 \\
\hline
\end{tabular}

Sumber data primer diolah,2019

Sesuai dengan hasil karakteristik usia responden yang mayoritas berusia 17-26 tahun, pekerjaan responden didominasi oleh Mahasiswa. Hal tersebut karena mahasiswa lebih memiliki banyak waktu senggang dan penghasilan yang masih terbatas sehingga membuat mayoritas mahasiswa lebih sering berbelanja bahan masakan daripada makanan jadi. Selain itu kalangan mahasiswa juga selalu mengikuti perkembangan zaman yang ada terutama dalam penggunaan media digital.

Hasil penelitian jumlah pengeluaran responden perbulan didominasi pada kisaran $\geq$ Rp. 1.500.000,-. Responden pada penelitian ini mayoritas responden melakukan belanja sayur dan kebutuhan dapur per minggu adalah setiap hari baik secara online maupun berbelanja langsung secara tradisional. Sedangkan frekuensi transaksi online secara umum mayoritas 1-2 per bulan.

Pada uji validitas dan reliabilitas menggunakan SEM melalui nilai Standardized Loading Factor (SLF), CR dan VE. Dari hasil perhitungan didapati semua indikator dapat dikatakan baik dan jawaban responden terhadap pertanyaan yang digunakan untuk mengukur masing-masing indikator adalah konsisten, dengan nilai $\mathrm{SLF} \geq 0,50$ yang menunjukkan valid atau tidak terdapat offending estimate, serta nilai $\mathrm{CR} \geq 0,70$ dan $\mathrm{VE} \geq 0,50$ yang menunjukkan relibilitas baik

Model awal dari uji kecocokan diketahui bahwa 12 dari 19 ukuran kecocokan GOF sudah masuk ke dalam kriteria baik dan 7 kriteria lainnya masih kurang baik. Karena model awal belum terlihat baik maka model awal ini harus mengalami respesifikasi agar model menjadi lebih baik. Model akhir dari uji kecocokan diketahui bahwa 15 dari 19 ukuran kecocokan GOF sudah masuk ke dalam kriteria baik yaitu Chi Square/ $X^{2}, \mathrm{X}^{2} / \mathrm{DF}, \mathrm{NCP}, \mathrm{SNCP}$ (NCP/n), RMSEA, ECVI, AIC, NFI, NNFI, CFI, IFI, RFI, GFI, PGFI, dan RMR.. Sedangkan CAIC, PNFI, AGFI dan CN kriteria masih kurang baik.

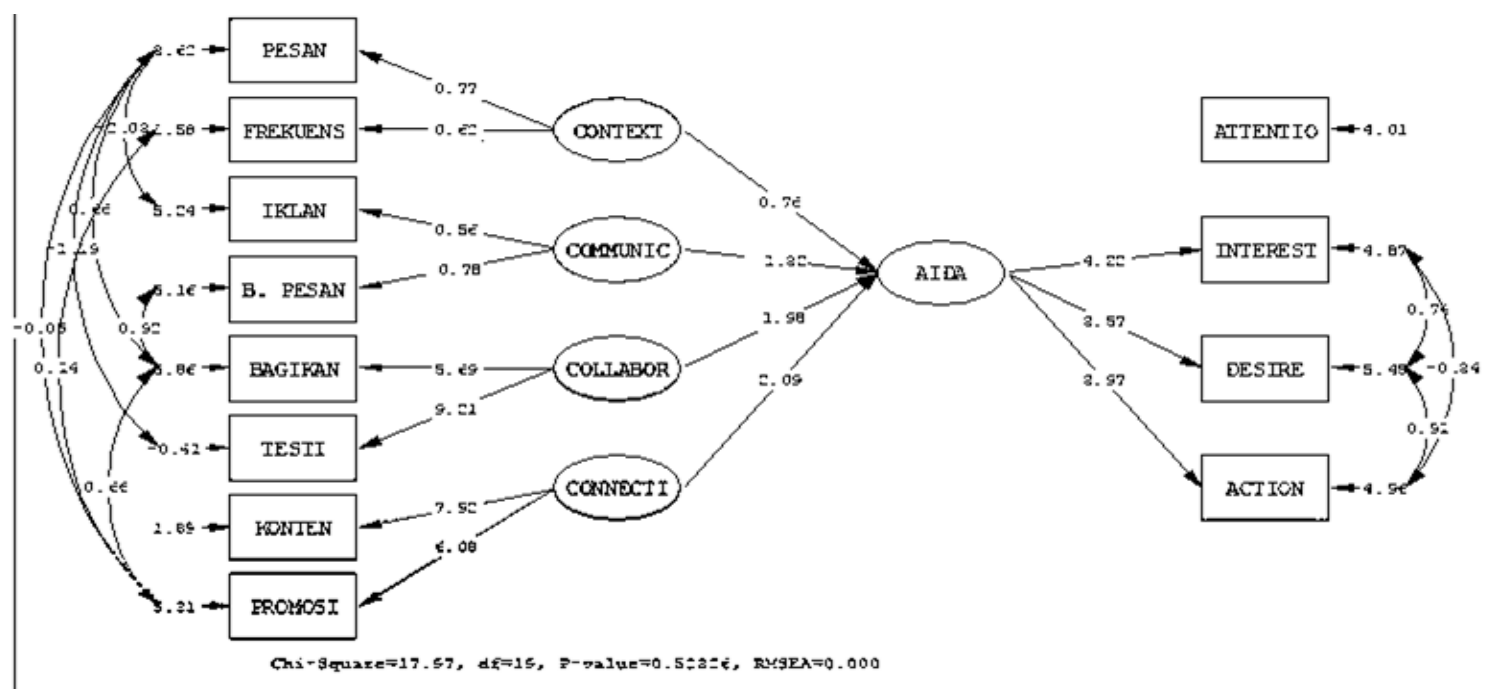

Gambar 1. Uji Signifikansi T-Value Model SEM Hasil Olahan

Sumber: Data Primer diolah, 2019 


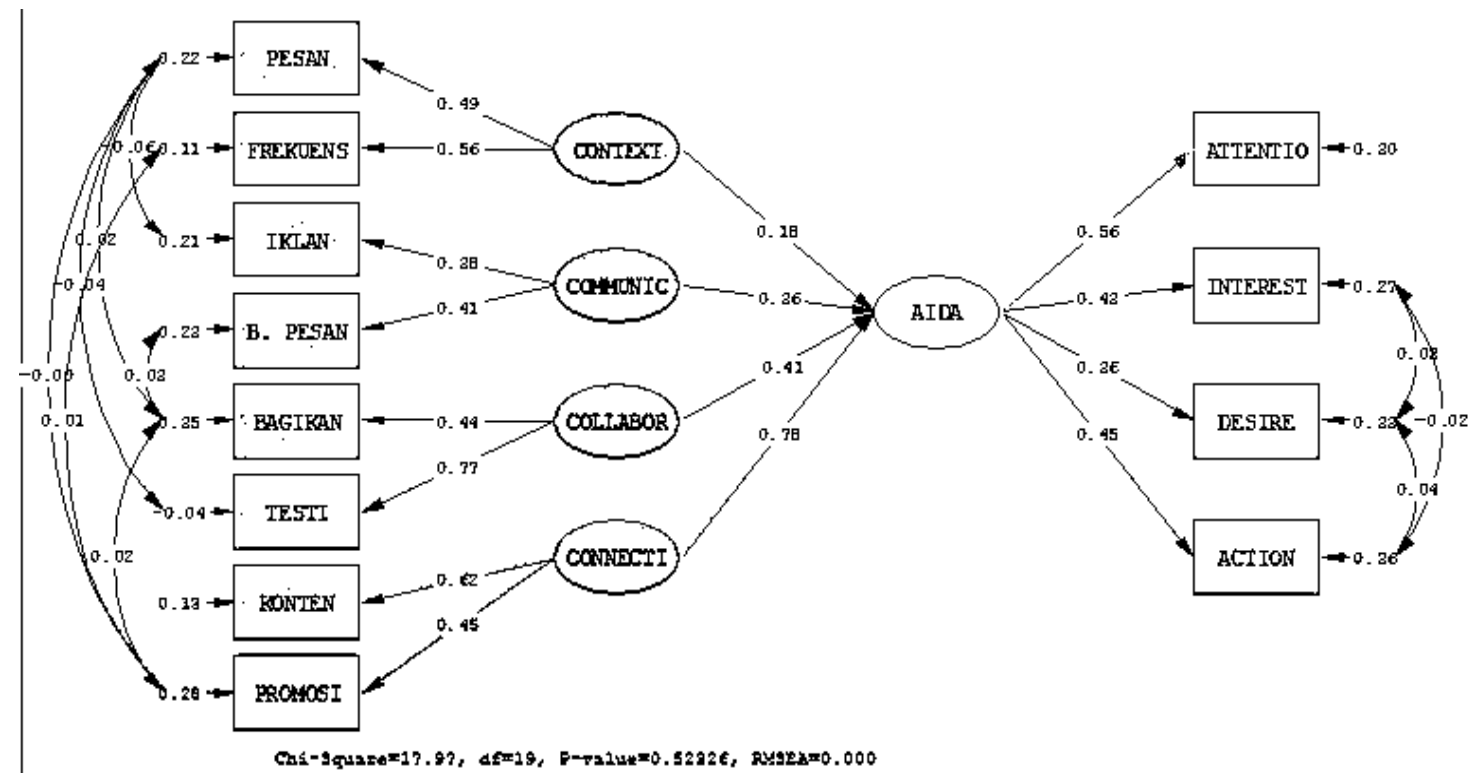

Gambar 2. Path Diagram Koefisien Estimasi Model Struktural

Sumber: Data Primer diolah, 2019

Untuk mengukur efektivitas internet yang dalam hal ini melalui media digital dapat dilihat dapat dilihat dari frekuensi kunjungan pelanggan terhadap suatu akun media digital produk, frekuensi pesan dan feedback, tingkat daya tarik pesan, lama kunjungan, serta jalan yang ditempuh untuk mencapai situs-situs media digital tertentu (Shimp, 2014). Namun context dalam penelitian ini ternyata tidak mempunyai pengaruh yang bermakna dalam pengambilan keputusan pembelian. Artinya pesan dan frekuensi pesan yang dilakukan CV.Sayurbaba Online Borneo belum maksimal. Temuan penelitian ini tidak mendukung hasil penelitian (Arief \& Millianyani, 2015), (Budiman, 2015) dan (Aiwan, Jessica, \& Jokom, 2016) yang mana dalam penelitiannya telah membuktikan adanya hubungan atau pengaruh positif antara context dengan keputusan pembelian.Hal ini dikarenakan frekuensi "Sayurbaba" dalam memposting konten di media digital tergolong jarang. Mayoritas responden mengatakan "Sayurbaba" hanya memposting konten seminggu sekali.

Context adalah bagaimana membentuk sebuah pesan atau informasi. Pesan atau informasi dalam hal ini yaitu gambar dan atau kalimat pada setiap postingan di media digital. Informasi ini digunakan untuk mengevaluasi semua alternatif yang ada dalam menentukan keputusan pembeliannya (Pamungkas \& Zuhroh, Pengaruh PromosiI Di Media Sosial Dan Word Of Mouth Terhadap Keputusan Pembelian, 2016). Sehingga context merupakan indikator yang penting untuk diperhatikan karena dapat meningkatkan penjualan.

Indikator pesan dan frekuensi tidak mendukung komponen context dalam membentuk keputusan pembelian konsumen "Sayurbaba". Jadi apabila pesan dan frekuensi yang disampaikan CV.Sayurbaba Online Borneo melalui media digital ditingkatkan maka tidak akan berpengaruh pada context promosi dalam pengambilan keputusan pembelian produk "Sayurbaba". 


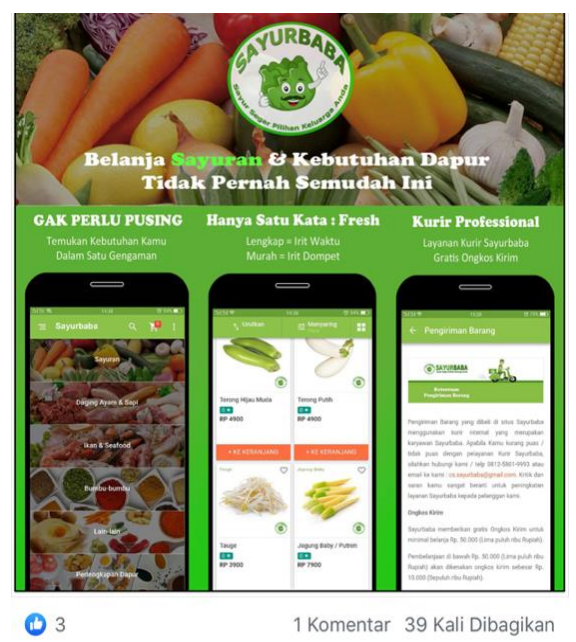

Gambar 3. Pesan "Sayurbaba" di media digital Facebook

Sumber: Akun media digital Facebook Sayurbaba , 2019

Variabel context yang dinilai responden masih kurang optimal yaitu mengenai frekuensi dalam memposting konten. Frekuensi admin media digital "Sayurbaba" dalam memposting sebuah konten dinilai masih kurang optimal karena dianggap jarang dalam memposting konten yakni hanya seminggu sekali. Frekuensi yang optimal dalam memposting sebuah konten yaitu maksimal 2 kali sehari untuk Facebook, 5 kali sehari atau lebih untuk Twitter dan 1-2 kali atau lebih untuk Instagram (Lee, 2018). Sedangkan hal yang dinilai responden paling optimal adalah cara penyampaian pesan yang mudah dimengerti. Pesan yang disampaikan oleh media digital "Sayurbaba" dinilai sudah menggunakan bahasa dan isi pesan yang jelas, singkat dan sesuai dengan kebutuhan informasi konsumen.

Communication adalah praktek dalam menyampaikan atau membagikan (sharing) dan juga mendengarkan, merespon, dan mengembangkan pesan atau informasi kepada khalayak (Solis, 2010). Pada penelitian ini diketahui bahwa Communication tidak memiliki pengaruh atau manfaat dalam pengambilan keputusan pembelian produk "Sayurbaba". Temuan ini tidak sejalan dengan penelitian (Indika \& Cindy, 2017) yang telah membuktikan bahwa komunikasi foto yang dikemas secara kreatif menjadi salah satu faktor yang cukup penting dalam menarik perhatian konsumen. Hal ini dikarenakan saat ini "Sayurbaba" tidak menggunakan periklanan di media digital dan lambat dalam membalas pesan konsumen. Mayoritas responden mengatakan "Sayurbaba" membalas pesan seminggu kemudian setelah responden mengajukan pertanyaan di media digital.

Communication bertujuan untuk mengelola hubungan dengan konsumen. Mengelola hubungan dengan konsumen merupakan proses megelola informasi rinci tentang masingmasing konsumen dan secara cermat mengelola semua "titik sentuhan" konsumen demi memaksimalkan kesetiaan konsumen (Kotler \& Keller, 2014). Pada intinya pentingnya melakukan komunikasi adalah untuk membangun kesetiaan konsumen, terus berupaya untuk memotivasi konsumen dan memilimalisir anggapan bahwa perusahaan hanya berorientasi pada produk melainkan sudah berorientasi pada konsumen.

Indikator periklanan dan balas pesan tidak mendukung komponen communication dalam membentuk keputusan pembelian konsumen "Sayurbaba". Jadi apabila periklanan dan 
balas pesan yang disampaikan CV.Sayurbaba Online Borneo melalui media digital ditingkatkan maka akan berpengaruh pada communication promosi media digital dalam pengambilan keputusan pembelian produk "Sayurbaba".

Variabel communication dinilai responden masih kurang optimal baik mengenai periklanan maupun balas pesan. Hal tersebut dikarenakan pada indikator periklanan, mayoritas responden mengatakan tidak pernah melihat "Sayurbaba" menggunakan iklan di media digital. Selain itu pada indikator balas pesan mayoritas responden mengatakan media digital "Sayurbaba" lambat dalam membalas pesan yakni seminggu kemudian setelah responden mengajukan pertanyaan. Hal ini tentunya harus ditingkatkan lebih baik lagi agar dapat memberikan pengaruh pada keputusan pembelian produk "Sayurbaba".

Collaboration adalah bagaimana bekerja sama untuk membuat segala hal menjadi lebih baik. Yaitu dengan kerja sama antara akun media digital "Sayurbaba" dengan konsumennya di media digital untuk membuat hal baik lebih efektif dan lebih efisien. Dalam penelitian ini terbukti bahwa collaboration atau kerja sama antara akun media digital "Sayurbaba" dengan konsumennya di media digital sudah terjalin cukup baik dan dapat mempengaruhi secara positif terhadap keputusan pembelian produk "Sayurbaba". Temuan ini sejalan dengan penelitian (Diyatma, 2017) dan (Abiyoso, 2018) yang telah membuktikan bahwa collaboration berpengaruh pada keputusan pembelian. Hal ini dikarenakan banyak konsumen yang membagikan postingan "Sayurbaba" dan memberikan testimoni atau pengalaman di media digital dalam berbelanja produk "Sayurbaba". Collaboration atau kerjasama dengan konsumen dapat membantu memperluas jaringan sebuah bisnis dan memperluas online audience. Berbagi konten dapat menyebabkan penjualan tidak langsung dan langsung tergantung pada jenis konten yang dibagikan (Gunelius, 2011).

Indikator membagikan postingan dan testimoni pelanggan bermakna atau berpengaruh dengan kontribusi yang cukup besar mendukung komponen collaboration dalam membentuk keputusan pembelian konsumen "Sayurbaba". Jadi apabila membagikan postingan dan testimoni pelanggan yang dilakukan konsumen "Sayurbaba" melalui media digital meningkat maka akan berpengaruh pada collaboration promosi media digital dalam pengambilan keputusan pembelian produk "Sayurbaba". Begitupula pada indikator.

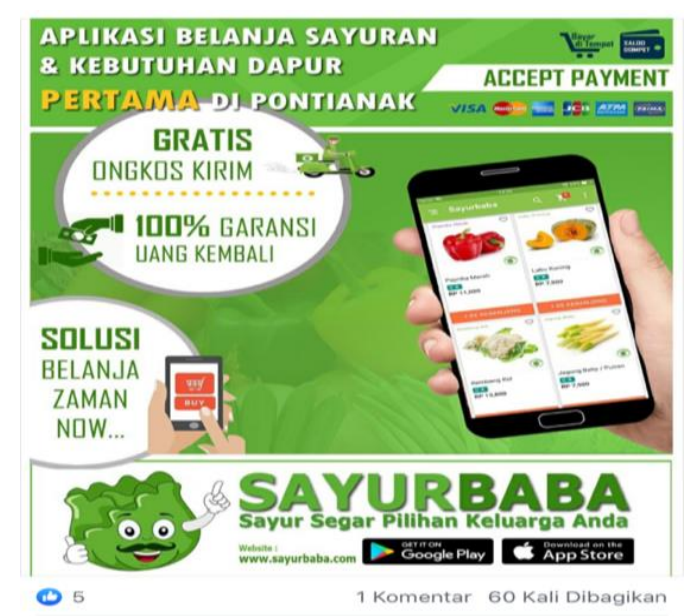

Gambar 4. Postingan "Sayurbaba" di media digital Facebook dibagikan oleh 60 konsumen 


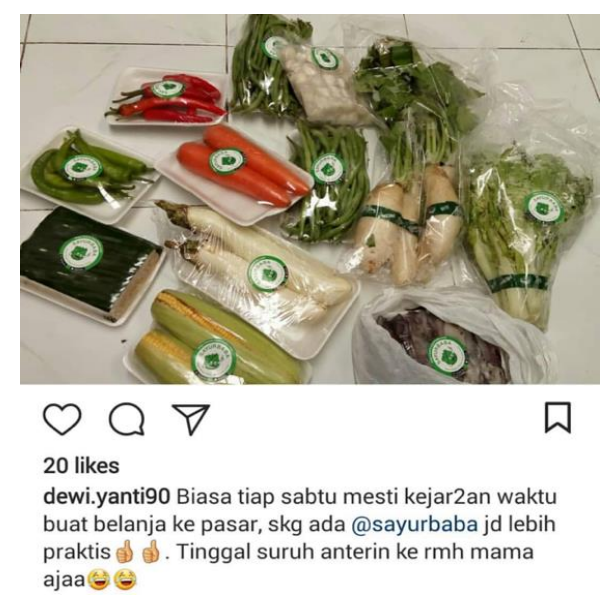

Gambar 5. Testimoni pelanggan "Sayurbaba" di media digital Instagram

Sumber: Akun media digital Instagram Sayurbaba , 2019

Variabel collaboration yang dinilai responden masih kurang optimal yaitu mengenai membagikan postingan. Hal tersebut dikarenakan pada indikator membagikan postingan mayoritas responden mengatakan jarang melihat konsumen membagikan postingan kepada orang lain tentang produk yang diposting "Sayurbaba". Sedangkan hal yang dinilai responden sudah optimal adalah indikator testimoni pelanggan. Konsumen "Sayurbaba" terlibat dalam membagikan pengalaman mereka berbelanja produk "Sayurbaba" melalui media digital.

Connection adalah bagaimana memelihara hubungan yang telah terbina. Bisa dengan melakukan sesuatu yang bersifat berkelanjutan sehingga konsumen merasa lebih dekat dengan "Sayurbaba". Hal tersebut dilakukan untuk meningkatkan loyalitas pelanggan dengan produk "Sayurbaba". Dalam penelitian ini diketahui bahwa connection berpengaruh positif dalam meningkatkan pengambilan keputusan pembelian produk "Sayurbaba". Temuan ini sejalan dengan hasil penelitian yang telah dilakukan (Fathurroyyan, 2017) yang membuktikan bahwa connection berpengaruh pada keputusan pembelian. Hal ini dikarenakan "Sayurbaba" telah membuat konten bermanfaat dan promosi-promosi yang dapat mempengaruhi keputusan pembelian konsumen.

Connection dengan konsumen penting untuk dibangun karena connection adalah salah satu perkembangan bisnis yang paling efektif dan signifikan pada abad ke 21 dan memberikan cara yang berbeda untuk berinteraksi dengan orang lain yang memiliki minat yang sama. Sosial media merupakan koneksi relasional yang memotivasi konsumen untuk berpartisipasi dan berkontribusi terhadap keputusan pembelian (Alsubagh, 2015).

Indikator konten bermakna atau berpengaruh dengan kontribusi yang cukup besar mendukung komponen connection dalam membentuk keputusan pembelian konsumen "Sayurbaba". Jadi apabila konten yang diposting "Sayurbaba" melalui media digital ditingkatkan maka akan berpengaruh pada connection promosi media digital dalam pengambilan keputusan pembelian produk "Sayurbaba". Dampak dari suatu konten dapat dilihat dari respon konsumen yang diwakili oleh like dan komentar tersebut. Semakin banyak jumlah like dan komentar maka semakin besar respon yang muncul dari konsumen. Dengan adanya respon yang banyak, hal ini menunjukkan bahwa suatu merek bisa menjalin hubungan dengan konsumen secara intens dan baik. Selain itu, jumlah like dan komentar yang 
SEA Volume 8, No. 2 (2019)

banyak juga akan membuka peluang untuk sebuah merek agar lebih popular dan dikenal (Santoso, Baihaqi, \& Persada, 2017).

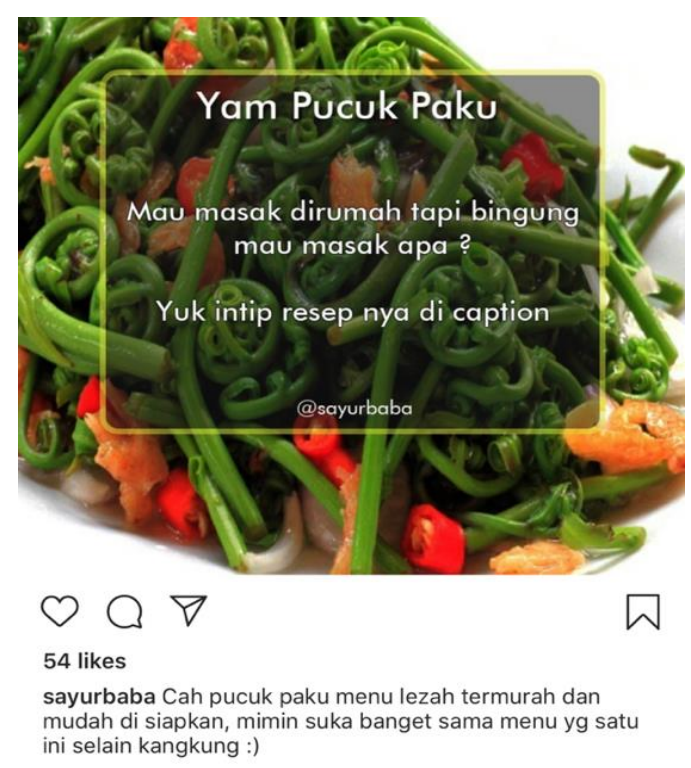

Gambar 6. "Sayurbaba" membagikan konten bermanfaat Resep Yam Pucuk Paku di media digital Instagram

Sumber: Akun media digital Instagram Sayurbaba , 2019

Indikator promosi bermakna atau berpengaruh dengan kontribusi yang cukup besar mendukung komponen connection dalam membentuk keputusan pembelian konsumen "Sayurbaba". Jadi apabila promosi yang dilakukan "Sayurbaba" melalui media digital ditingkatkan maka akan berpengaruh pada connection promosi media digital dalam pengambilan keputusan pembelian produk "Sayurbaba".

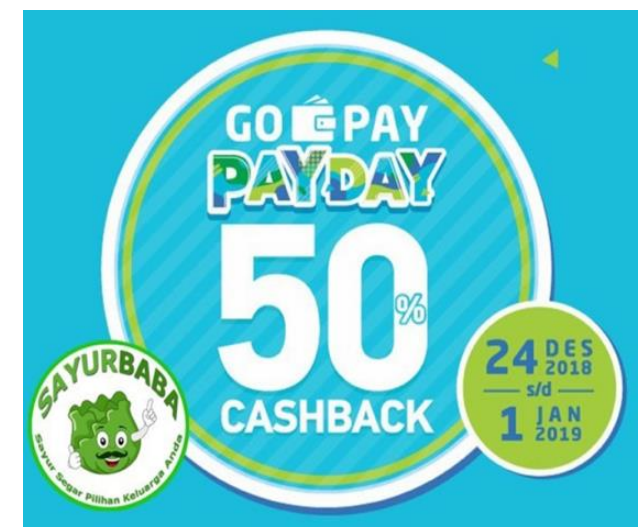

Gambar 7. Promosi yang dilakukan "Sayurbaba" di media digital

Sumber: Akun media digital Instagram Sayurbaba , 2019

Variabel connection dinilai responden sudah baik yaitu konten yang diposting media digital "Sayurbaba" bermanfaat dan promosi yang diadakan "Sayurbaba" menarik perhatian konsumen. Artinya admin media digital "Sayurbaba" telah berhasil menjalin hubungan yang berkelanjutan dengan konsumen. 
Tabel 2. Jalur Promosi Media Digital Terhadap Keputusan Pembelian

\begin{tabular}{lc}
\hline \multicolumn{1}{c}{ Jalur (Path) } & Total Effect \\
\hline Context $\rightarrow$ Keputusan Pembelian & 0.18 \\
\hline Communication $\rightarrow$ Keputusan Pembelian & 0.36 \\
\hline Collaboration $\rightarrow$ Keputusan Pembelian & 0.41 \\
\hline Connection $\rightarrow$ Keputusan Pembelian & 0.78 \\
\hline \multicolumn{1}{c}{ Sumber $:$ Data Primer diolah, 2019 } &
\end{tabular}

Pada tabel diatas terdapat 4 jalur untuk menggambarkan efek dari variabel laten pada keputusan pembelian. Terdapat dua variabel laten bebas yang berpengaruh langsung pada keputusan pembelian yaitu variabel collaboration dengan pengaruh total sebesar $41 \%$ dan variabel connection dengan pengaruh total sebesar 78\%. Hal ini menunjukkan bahwa collaboration dan connection menjadi aspek yang paling penting untuk mempengaruhi keputusan pembelian produk "Sayurbaba".

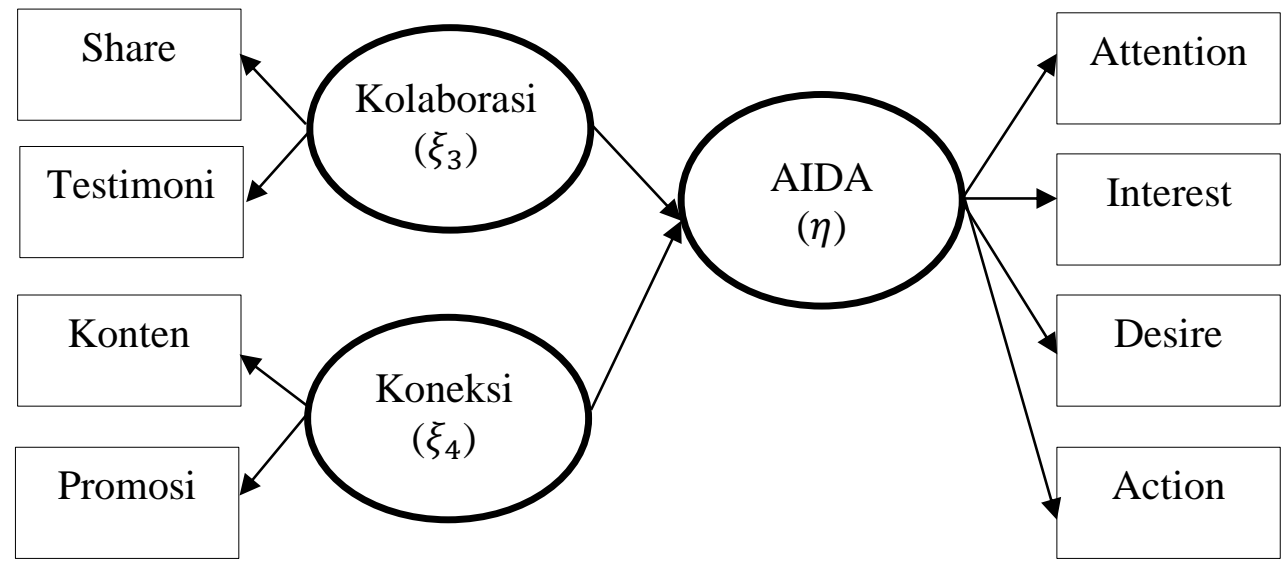

Gambar 8. Promosi Aplikasi “Sayurbaba” Terhadap Keputusan Pembelian Melalui Media Digital Di Kota Pontianak

\section{KESIMPULAN}

Berdasarkan penelitian yang telah dilakukan pada promosi aplikasi "Sayurbaba" di media digital, dari empat variabel promosi yang terdiri dari context, communication, collaboration, dan connection, promosi aplikasi "Sayurbaba" terhadap keputusan pembelian melalui media digital di kota Pontianak hanya terbentuk dari dua variabel laten bebas yaitu variabel collaboration dan connection sebagaimana telah digambarkan pada diagram di atas. Hal ini menunjukkan bahwa variabel collaboration dan connection merupakan aspek promosi yang paling penting dalam mempengaruhi keputusan pembelian konsumen. Sehingga hal yang perlu diperhatikan untuk meningkatkan minat beli konsumen "Sayurbaba" adalah membagikan postingan, testimoni pelanggan, konten yang bermanfaat dan promosi.

\section{DAFTAR PUSTAKA}

Abiyoso, A. (2018). Pengaruh Context, Communication, Collaboration Dan Connection Terhadap Minat Beli. Jakarta: Universitas Bakri.

Aiwan, N. B., Jessica, E., \& Jokom, R. (2016). Analisa Efektivitas Komunikasi Pemasaran Interaktif Melalui Instagram Menggunakan Customer Response Index. Universitas Kristen Petra. 
SEA Volume 8, No. 2 (2019)

Alsubagh, H. (2015). The Impact of Social Networks on Consumers Behaviours. International Journal of Business and Social Science, 209-216.

Arief, G. M., \& Millianyani, H. (2015). Pengaruh Social Media Marketing Melalui Instagram Terhadap Minat Beli Konsumen Sugar Tribe. e-Proceeding of Management, 25812587.

Budiman, A. (2015). Social Media And Brand Image. Universitas Pendidikan Indonesia.

Coelho, R. L., Oliveira, D. S., \& Almeida, M. I. (2016). Does Social Media Matter for Post Typology? Impact of Post Content on Facebook and Instagram Metrics. Online Information Review, 458-471.

Diyatma, A. J. (2017). Pengaruh Promosi Melalui Media Sosial Instagram Terhadap Keputusan Pembelian Produk Saka Bistro\&Bar. e-Proceeding of Management, 175179.

Fathurroyyan, M. (2017). Pengaruh Social Media Terhadap Peningkatan Brand Awareness Clover Clothing Melalui Instagram. Skripsi. Bandung: Universitas Pendidikan Indonesia.

Ghozali, I., \& Fuad. (2012). Structural Equation Modeling Teori, Konsep dan Aplikasi dengan Program Lisrel 8.80. Semarang: Universitas Diponegoro.

Gunelius, S. (2011). 30 Minute Social Media Marketing. United States: MC.Graw Hill.

Helianthusonfri, J. (2014). 1 Juta Rupiah Pertama Anda Dari Facebook. Jakarta: Alex Media Komputindo.

Indika, D. R., \& Cindy, J. (2017). Media Sosial Sebagai Sarana Promosi Untuk Meningkatkan Minat Beli Konsumen. Jurnal Bisnis Terapan, 25-32.

Kotler, P., \& Keller, K. (2014). Marketing management 15th Edition . New Jersey: Pearson Education, Inc.

Lee, K. (2018, November 30). Infographic: How Often Should You Post on Social Media? See The Most Popular Research and Tips. Dipetik December 6, 2019, dari Buffer Marketing Library: https://buffer.com/library/how-often-post-social-media

Lin, Y. F., \& Chiu, Y. P. (2015). Influence of Facebook Brand-page Posts on Online engagement. Online Information Review, 505-519.

Pamungkas, B. A., \& Zuhroh, S. (2016). Pengaruh Promosi Di Media Sosial Dan Word Of Mouth Terhadap Keputusan Pembelian. Komunikasi, Vol. X No. 02, 145-160.

Ryan, K. S., \& Zabin, J. (2010). Gleansight: Social Media Marketing. Gleanster LCC, 1-21.

Santoso, A. P., Baihaqi, I., \& Persada, S. F. (2017). Pengaruh Konten Post Instagram terhadap Online Engagement: Studi Kasus pada Lima Merek Pakaian Wanita. Jurnal Teknik ITS, 217-221.

Shimp, A. (2014). Komunikasi Pemasaran Terpadu Dalam Periklanan Dan Promosi. Jakarta: Salemba Empat.

Solis, B. (2010). Engage : The Complete Guide for Brands and Business to Build, Cultivate, and Measure Success in the New Web. New Jersey: Wiley \& Sons Inc.

Sumarwan, U. (2011). Perilaku Konsumen. Bogor: Ghalia Indonesia.

Vries, L. d., Gensler, S., \& Leeflang, P. S. (2012). Popularity of Brand Posts on Brand Fan Pages: An Investigation of the Effects of Social Media. Journal of Interactive Marketing, 83-91. 